\title{
PENENTUAN STATUS MUTU AIR WADUK SERMO DENGAN METODE STORET DAN INDEKS PENCEMARAN
}

\author{
Lussya Setya Dewi ${ }^{1}$, Intan Supraba ${ }^{2}$, Budi Kamulyan ${ }^{3}$ \\ 1) 2) 3) Departemen Teknik Sipil dan Lingkungan, Universitas Gadjah Mada, Yogyakarta \\ Email : lussya.setyadewi@gmail.com
}

\begin{abstract}
Abstrak
Waduk Sermo dimanfaatkan sebagai air baku air minum oleh PDAM Tirta Binangun. Untuk memenuhi syarat sebagai air baku air minum, kualitas air Waduk Sermo harus memenuhi persyaratan yang tertulis dalam Peraturan Gubernur DIY nomor 20 tahun 2008 tentang Baku Mutu Air di Provinsi Daerah Istimewa Yogyakarta. Penelitian yang pernah dilakukan menyatakan bahwa budidaya ikan dengan keramba jaring apung menyebabkan pencemaran ringan di Waduk Sermo. Penelitian lain yang pernah dilakukan menyatakan bahwa status mutu air Waduk Sermo pada tahun 2010, 2011, dan 2012 yang dihitung dengan metode Indeks Pencemaran (IP) adalah tercemar ringan. Penelitian ini bertujuan untuk mengetahui status mutu air Waduk Sermo setelah keramba jaring apung dilarang beroperasi di Waduk Sermo berdasarkan beberapa parameter kualitas air Waduk Sermo yang dibandingkan dengan Peraturan Gubernur DIY nomor 20 tahun 2008. Penentuan status mutu air menggunakan metode STORET dan Indeks Pencemaran (IP). Kedua metode ini menggunakan prinsip perbandingan antara data kualitas air di lapangan dengan baku mutu air sesuai peruntukannya. Data kualitas air sebagai input kedua metode tersebut diperoleh dengan cara sampling dan uji laboratorium. Parameter kualitas air yang digunakan adalah TDS, pH, temperatur, fosfat, kekeruhan, nitrit, nitrat, NH3-N, dan DO. Dari hasil perhitungan dengan metode STORET diketahui bahwa Waduk Sermo memiliki status mutu air tercemar sedang sedangkan hasil perhitungan dengan metode Indeks Pencemaran (IP) diketahui bahwa Waduk Sermo masih memiliki status mutu air tercemar ringan. Hal ini menandakan bahwa masih terdapat sumber pencemaran lain selain keramba jaring apung.
\end{abstract}

Kata kunci: indeks pencemaran, status mutu air, STORET

\begin{abstract}
Sermo reservoir is used by PDAM Tirta Binangun as raw water for drinking water. To be qualified as raw water for drinking, the quality of water in Waduk Sermo must be on par with the requirements written in the Regulation of Daerah Istimewa Yogyakarta Governor number 20 year of 2008. In previous research, it is stated that fish farming with floating net cages causes mild pollution in Sermo Reservoir. Another research stated that the status of water quality in Sermo Reservoir in the year of 2010, 2011 and 2012 calculated with Pollution Index (PI) method serve the result as mild polluted. This research aims to determine the status of water quality in Sermo Reservoir after floating net cages prohibited from operation in Sermo Reservoir based on several parameters of Sermo Reservoir's water quality compared with the Regulation of DIY Governor number 20 year of 2018. STORET method and Pollution Index (PI) used to determine status of water quality. Both of the methods uses the principle of comparison between water quality data from the fields and the water quality standards according to its purposes. Water quality data as an input for both of the methods obtained by sampling and laboratory testing. Parameter of water quality such as TDS, pH, temperature, phosphate, turbidity, nitrite, nitrate, $\mathrm{NH}_{3}-\mathrm{N}$, and DO. Calculation result with STORET method stated that Sermo Reservoir has a moderate pollution status, while calculation result with the Pollution Index (PI) method stated that Sermo Reservoir still has a mild pollution status. All of this indicates that there are another sources of pollution besides the floating net cages.
\end{abstract}

Keywords: pollution index, water quality status, STORET

\section{PENDAHULUAN}

Kawasan objek wisata Waduk Sermo adalah salah satu objek wisata yang memiliki kekhasan tersendiri. Waduk Sermo dibangun untuk mewujudkan suplesi sistem irigasi daerah Kalibawang. Sistem irigasi tersebut merupakan interkoneksi dari beberapa daerah irigasi, Dikirim/submitted: 6 Desember 2019

Diterima/accepted: 13 Desember 2019 
diantaranya Clereng, Pengasih, dan Pekik Jamal. Pembangunan waduk ini selain sebagai suplesi sistem irigasi juga digunakan sebagai kawasan objek wisata. Pembangunan di waduk ini membawa perubahan pada mata pencaharian dan peningkatan pendapatan masyarakat Sremo, muncul lapangan kerja baru, meningkatnya kesejahteraan, akses jalan mudah, dan pola pikir masyarakat yang lebih maju (Rahmayanti dan Pinasti, 2018).

Perusahaan Daerah Air Minum (PDAM) Tirta Binangun juga memanfaatkan Waduk Sermo sebagai sumber air baku air minum. Untuk memenuhi syarat sebagai air baku air minum, kualitas air Waduk Sermo harus memenuhi persyaratan yang tertulis dalam Peraturan Gubernur DIY nomor 20 tahun 2008 tentang Baku Mutu Air di Provinsi Daerah Istimewa Yogyakarta. Air yang peruntukannya sebagai air baku air minum masuk ke dalam kategori air kelas satu sehingga air Waduk Sermo harus memenuhi baku mutu kualitas air kelas satu di dalam peraturan tersebut.

Menurut Rustadi (2009), limbah organik dalam air dan sedimen waduk Sermo mengalami dekomposisi dan meningkatkan konsentrasi unsur nitrogen dan fosfor yang dapat mendorong pertumbuhan fitoplankton. Pada konsentrasi optimum, unsur hara tersebut menguntungkan bagi produksi ikan di waduk karena fitoplankton merupakan sumber makanan ikan. Penelitian yang dilakukan oleh Yulianto (2002), Wulandari (2014) menyatakan bahwa budidaya ikan dengan keramba jaring apung di waduk sermo justru menyebabkan pencemaran ringan di Waduk Sermo. Hal ini diduga karena tingginya unsur nitrogen dan fosfor akibat aktivitas budidaya ikan. Bahari (2015) menyatakan bahwa status mutu air Waduk Sermo pada tahun 2010, 2011, dan 2012 yang dihitung dengan metode Indeks Pencemaran (IP) adalah tercemar ringan.

Pada tahun 2018 tidak ditemukan adanya budidaya ikan dengan keramba jaring apung dan restoran apung di perairan Waduk Sermo. Hal ini sebagai tindak lanjut dari larangan yang dikeluarkan oleh Bupati Kulon Progo pada tahun 2014 mengingat bahwa keramba jaring apung dan restoran apung menyebabkan pencemaran di Waduk Sermo. Penelitian ini bertujuan untuk mengetahui status mutu air Waduk Sermo setelah keramba jaring apung dan restoran apung dilarang beroperasi di Waduk Sermo berdasarkan beberapa parameter kualitas air Waduk Sermo yang dibandingkan dengan Peraturan Gubernur DIY nomor 20 tahun 2008. Penentuan status mutu air menggunakan metode STORET dan Indeks Pencemaran (IP). 
Suatu sumber air harus memenuhi baku mutu. Wilayah Daerah Istimewa Yogyakarta menggunakan Peraturan Gubernur DIY nomor 20 tahun 2008 sebagai baku mutu air. Apabila peruntukannya adalah sebagai air baku air minum maka harus memenuhi baku mutu air kelas satu (I). Penentuan status mutu air menggunakan metode STORET dan Indeks Pencemaran sesuai dengan Keputusan Menteri Negara Lingkungan Hidup nomor 115 tahun 2003 tentang Pedoman Penentuan Status Mutu Air. Menurut Huboyo dkk. (2009), penggunaan dua metode ini seringkali menghasilkan output yang berbeda, karena adanya pembobotan tiap-tiap parameter yang berbeda. Oleh karena itu perlu kajian mengenai perbandingan dua metode tersebut agar pemakaian masing-masing metode dapat digunakan sesuai dengan kondisi yang sesuai.

\section{METODE PENELITIAN}

Studi literatur dilakukan pada awal penelitian ini untuk mengetahui kondisi Waduk Sermo pada saat keramba jaring apung masih beroperasi. Studi literatur juga dilakukan untuk mengetahui metode yang digunakan untuk penentuan status mutu air di Indonesia beserta langkah-langkah perhitungannya. Selain itu studi literatur juga dilakukan untuk mengetahui aturan yang dijadikan baku mutu air wilayah Daerah Istimewa Yogyakarta. Di dalam aturan ini juga dijelaskan baku mutu untuk setiap kelas dan parameter kualitas air.

Penentuan titik sampel dan pengambilan sampel air kemudian dilakukan dengan purposive sampling. Titik sampel air yang diambil berada di daerah bekas keramba jaring apung dan restoran apung beserta titik-titik masuknya aliran air yang menuju Waduk Sermo. Selain itu titik sampel juga ada yang terdapat di dekat intake PDAM Tirta Binangun. Dalam penelitian ini jumlah titik sampel ada 7 titik dan ditunjukkan di dalam Gambar 2 di bawah ini. Pengambilan sampel dilakukan selama 6 bulan yaitu pada bulan Agustus 2018 sampai dengan Januari 2019. Pengambilan sampel dilakukan pada pukul 08.00 sampai dengan 10.00 WIB. Gambar 1 menunjukkan detail titik pengambilan sampel.

Setelah dilakukan pengambilan sampel air, tahap penelitian dilanjutkan pada pengujian sampel di laboratorium. Pada penelitian ini, laboratorium yang digunakan adalah Laboratorium Teknik Penyehatan Lingkungan Departemen Teknik Sipil dan Lingkungan UGM. Parameter kualitas air yang diuji adalah TDS, $\mathrm{pH}$, temperatur, fosfat, kekeruhan, nitrit, nitrat, $\mathrm{NH}_{3}-\mathrm{N}$, dan DO. 


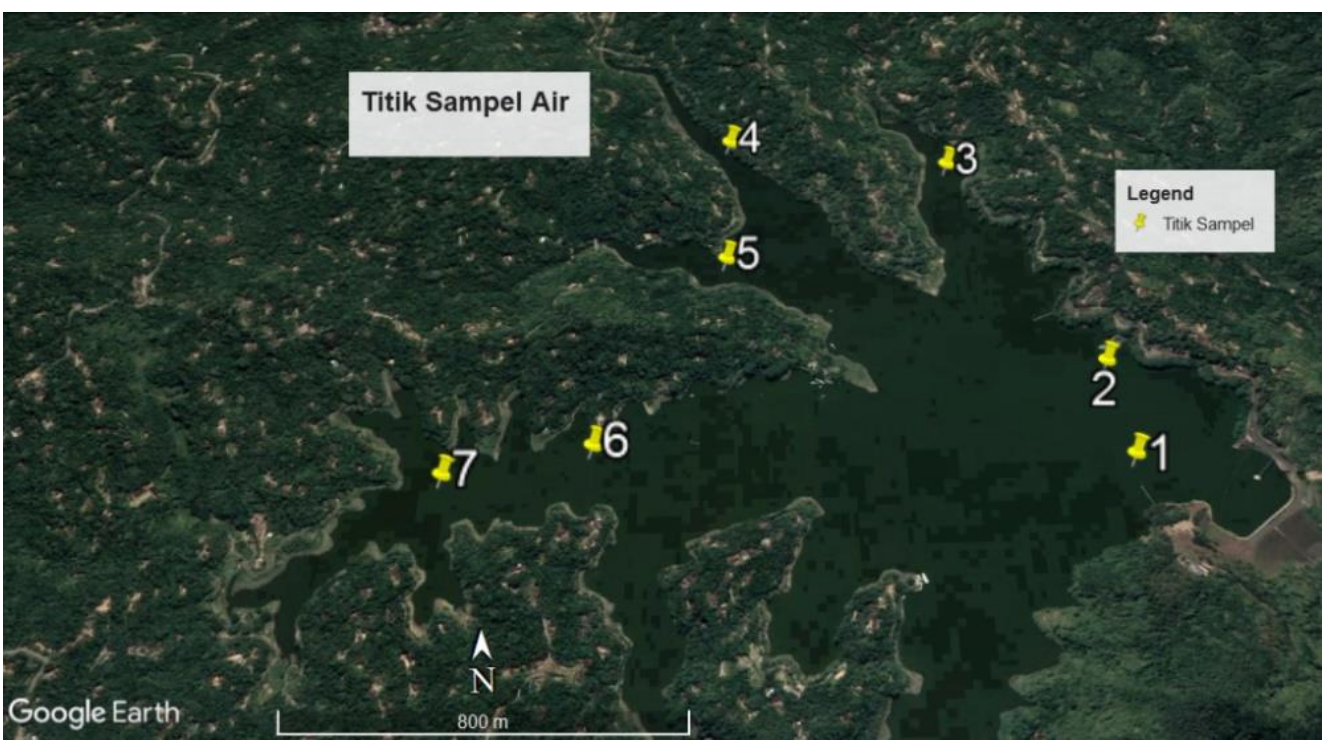

Gambar 1. Titik pengambilan sampel air

Pengolahan data hasil uji laboratorium menggunakan metode yang ada di dalam Keputusan Menteri Negara Lingkungan Hidup nomor 115 tahun 2003 tentang Pedoman Penentuan Status Mutu Air yaitu metode STORET dan Indeks Pencemaran. Di dalam Tabel 1 dijelaskan baku mutu air kelas satu untuk beberapa parameter kualitas air yang digunakan dalam penelitian ini yang mengacu pada Peraturan Gubernur DIY nomor 20 tahun 2008.

Tabel 1. Baku mutu air kelas satu

\begin{tabular}{cccc}
\hline Parameter & Satuan & Nilai & Jenis parameter \\
\hline TDS (Total Dissolved Solid) & $\mathrm{mg} / \mathrm{L}$ & 1000 & Fisika \\
\hline $\mathrm{pH}$ & - & $6-8,5$ & Kimia \\
\hline Temperatur & ${ }^{\circ} \mathrm{C}$ & \pm 3 terhadap suhu udara & Fisika \\
\hline Fosfat & $\mathrm{mg} / \mathrm{L}$ & 0,2 & Kimia \\
\hline Kekeruhan & $\mathrm{NTU}$ & 5 & Fisika \\
\hline Nitrit & $\mathrm{mg} / \mathrm{L}$ & 0,06 & Kimia \\
\hline Nitrat & $\mathrm{mg} / \mathrm{L}$ & 10 & Kimia \\
\hline $\mathrm{NH}_{3}-\mathrm{N}$ & $\mathrm{mg} / \mathrm{L}$ & 0,5 & Kimia \\
\hline DO (Dissolved Oxygen) & $\mathrm{mg} / \mathrm{L}$ & 6 & Kimia \\
\hline
\end{tabular}

Penentuan status mutu air menggunakan metode STORET dan Indeks Pencemaran sesuai dengan Keputusan Menteri Negara Lingkungan Hidup nomor 115 tahun 2003 tentang Pedoman Penentuan Status Mutu Air. Di dalam metode STORET, klasifikasi mutu air terbagi di dalam empat kelas seperti yang dijelaskan pada Tabel 2. 
Tabel 2. Klasifikasi mutu air menurut metode STORET

\begin{tabular}{ccc}
\hline Kelas & Total skor & Keterangan \\
\hline A & 0 & Memenuhi baku mutu \\
B & $-1 \mathrm{~s} / \mathrm{d}-10$ & Tercemar ringan \\
C & $-11 \mathrm{~s} / \mathrm{d}-30$ & Tercemar sedang \\
D & $\geq-31$ & Tercemar berat \\
\hline
\end{tabular}

Untuk parameter yang memenuhi baku mutu diberi skor 0. Untuk parameter yang tidak memenuhi baku mutu diberi skor seperti yang tertulis dalam Tabel 3. Jumlah dari skor negatif berdasarkan Tabel 3 menjadi dasar untuk menentukan status mutu air.

Tabel 3. Penentuan sistem skor untuk menentukan status mutu air

\begin{tabular}{ccccc}
\hline \multirow{2}{*}{$\begin{array}{c}\text { Jumlah } \\
\text { parameter }\end{array}$} & Nilai & \multicolumn{3}{c}{ Jenis parameter } \\
\cline { 3 - 5 } & & Fisika & Kimia & Biologi \\
\hline$<10$ & Maksimum & -1 & -2 & -3 \\
& Minimum & -1 & -2 & -3 \\
& Rata-rata & -3 & -6 & -9 \\
\hline$\geq 10$ & Maksimum & -2 & -4 & -6 \\
& Minimum & -2 & -4 & -6 \\
& Rata-rata & -6 & -12 & -18 \\
\hline
\end{tabular}

Metode Indeks Pencemaran merupakan metode yang diusulkan oleh Sumitomo dan Nemerow (1970) yang tertulis dalam Keputusan Menteri Negara Lingkungan Hidup nomor 115 tahun 2003. Di dalam metode Indeks Pencemaran (IP), klasifikasi mutu air terbagi di dalam empat kelas seperti yang dijelaskan pada Tabel 4.

Tabel 4. Klasifikasi mutu air menurut metode Indeks Pencemaran

\begin{tabular}{cc}
\hline Nilai $\mathbf{P I}_{\mathbf{j}}$ & Keterangan \\
\hline $0 \leq \mathrm{PI}_{\mathrm{j}} \leq 1,0$ & Memenuhi baku mutu (kondisi baik) \\
$1,0<\mathrm{PI}_{\mathrm{j}} \leq 5,0$ & Tercemar ringan \\
$5,0<\mathrm{PI}_{\mathrm{j}} \leq 10$ & Tercemar sedang \\
$\mathrm{PI}_{\mathrm{j}}>10$ & Tercemar berat \\
\hline
\end{tabular}

Penentuan nilai $\mathrm{PI}_{\mathrm{j}}$ membutuhkan beberapa tahap yang diacu dari Keputusan Menteri Negara Lingkungan Hidup nomor 115 tahun 2003. Parameter yang digunakan dalam menentukan nilai $\mathrm{PI}_{\mathrm{j}}$ adalah $\mathrm{C}_{\mathrm{i}}$ dan $\mathrm{L}_{\mathrm{ij}}$. Nilai $\mathrm{C}_{\mathrm{i}}$ merupakan konsentrasi parameter kualitas air yang diperoleh dari hasil analisis cuplikan air pada suatu lokasi pengambilan sampel sedangkan nilai $\mathrm{L}_{\mathrm{ij}}$ merupakan konsentrasi parameter kualitas air yang dicantumkan dalam baku mutu sesuai peruntukan air sehingga $\mathrm{PI}_{\mathrm{j}}$ merupakan Indeks Pencemaran bagi peruntukan yang merupakan fungsi dari $\mathrm{C}_{\mathrm{i}} / \mathrm{L}_{\mathrm{ij}}$. Urutan tahapan penentuan nilai $\mathrm{PI}_{\mathrm{j}}$ adalah sebagai berikut ini. 
1. Parameter - parameter yang jika harga parameter rendah maka kualitas air semakin baik dipilih terlebih dahulu

2. Konsentrasi parameter baku mutu yang tidak memiliki rentang juga dipilih terlebih dahulu

3. Harga $\mathrm{C}_{\mathrm{i}} / \mathrm{L}_{\mathrm{ij}}$ pengukuran untuk setiap parameter pada setiap lokasi sampling dihitung

4. Jika $C_{i} / L_{i j}$ pengukuran $<1,0$ maka nilai $C_{i} / L_{i j}$ baru menggunakan nilai $C_{i} / L_{i j}$ pengukuran

5. Jika $\mathrm{C}_{\mathrm{i}} / \mathrm{L}_{\mathrm{ij}}$ pengukuran $>1,0$ maka nilai $\mathrm{C}_{\mathrm{i}} / \mathrm{L}_{\mathrm{ij}}$ baru menggunakan nilai dari persamaan:

$$
\left(\mathrm{C}_{\mathrm{i}} / \mathrm{L}_{\mathrm{ij}}\right)_{\text {baru }}=1+\mathrm{P} \log \left(\mathrm{C}_{\mathrm{i}} / \mathrm{L}_{\mathrm{ij}} \text { pengukuran }\right)
$$

Nilai P biasanya menggunakan 5

6. Jika ditemukan konsentrasi parameter yang menurun menyatakan tingkat pencemaran meningkat (misal DO), maka terlebih dahulu menentukan nilai maksimum $\mathrm{C}_{\mathrm{im}}$. Untuk DO nilai maksimum $\mathrm{C}_{\mathrm{im}}$ merupakan nilai DO jenuh. Nilai DO jenuh tergantung dari temperatur air. Dalam kasus ini nilai $\mathrm{C}_{\mathrm{i}} / \mathrm{L}_{\mathrm{ij}}$ pengukuran diganti dengan nilai $\mathrm{C}_{\mathrm{i}} / \mathrm{L}_{\mathrm{ij}}$ baru yaitu:

$$
\left(\mathrm{C}_{\mathrm{i}} / \mathrm{L}_{\mathrm{ij}}\right)_{\text {baru }}=\frac{\mathrm{C}_{\mathrm{im}}-\mathrm{C}_{\mathrm{i}(\text { pengukuran })}}{\mathrm{C}_{\mathrm{im}}-\mathrm{L}_{\mathrm{ij}}}
$$

Nilai DO jenuh menurut temperatur air West Virginia Department of Environmental Protection (2019) dan ditampilkan dalam Tabel 5 berikut ini.

Tabel 5. Nilai DO jenuh menurut temperatur air

\begin{tabular}{cc}
\hline Temperatur $\left({ }^{\circ} \mathrm{C}\right)$ & DO jenuh $(\mathrm{mg} / \mathrm{L})$ \\
\hline 27 & 8,1 \\
28 & 7,9 \\
29 & 7,8 \\
30 & 7,7 \\
\hline
\end{tabular}

7. Jika nilai baku mutu $\mathrm{L}_{\mathrm{ij}}$ mempunyai rentang maka:

- Untuk $\mathrm{C}_{\mathrm{i}} \leq \mathrm{L}_{\mathrm{ij}}$ rata-rata

$$
\left(\mathrm{C}_{\mathrm{i}} / \mathrm{L}_{\mathrm{ij}}\right)_{\text {baru }}=\frac{\mathrm{C}_{\mathrm{i}}-\mathrm{L}_{\mathrm{ij}} \text { rata-rata }}{\mathrm{L}_{\mathrm{ij} \text { min }}-\mathrm{L}_{\mathrm{ij}} \text { rata-rata }}
$$

- Untuk $\mathrm{C}_{\mathrm{i}} \geq \mathrm{L}_{\mathrm{ij}}$ rata-rata

$$
\left(\mathrm{C}_{\mathrm{i}} / \mathrm{L}_{\mathrm{ij}}\right)_{\text {baru }}=\frac{\mathrm{C}_{\mathrm{i}}-\mathrm{L}_{\mathrm{ij}} \text { rata-rata }}{\mathrm{L}_{\mathrm{ij}} \text { max }-\mathrm{L}_{\mathrm{ij}} \text { rata-rata }}
$$

8. Menentukan nilai rata-rata dan nilai maksimum dari keseluruhan $\left(\mathrm{C}_{\mathrm{i}} / \mathrm{L}_{\mathrm{ij}}\right)$ baru yaitu $\left(\mathrm{C}_{\mathrm{i}} / \mathrm{L}_{\mathrm{ij}}\right)_{\mathrm{R}} \operatorname{dan}\left(\mathrm{C}_{\mathrm{i}} / \mathrm{L}_{\mathrm{ij}}\right)_{\mathrm{M}}$

9. Menentukan harga $\mathrm{PI}_{\mathrm{j}}$ dengan persamaan: 


$$
\mathrm{PI}_{\mathrm{j}}=\sqrt{\frac{\left(\mathrm{C}_{\mathrm{i}} / \mathrm{L}_{\mathrm{ij}}\right)_{\mathrm{M}}^{2}+\left(\mathrm{C}_{\mathrm{i}} / \mathrm{L}_{\mathrm{ij}}\right)_{\mathrm{R}}^{2}}{2}}
$$

\section{HASIL DAN PEMBAHASAN}

Pada penelitian ini, terdapat sembilan parameter air yang diuji laboratorium yaitu total dissolved solid (TDS), $\mathrm{pH}$, temperatur, fosfat, kekeruhan, nitrit, nitrat, $\mathrm{NH}_{3}-\mathrm{N}$, dan dissolved oxygen (DO). Pengambilan sampel air dilakukan pada tujuh titik selama periode enam bulan. Hasil uji laboratorium untuk sampel air yang diambil pada titik sampel 1 dan titik sampel 2 dijelaskan dalam tabel 6. Hasil uji laboratorium pada titik sampel 3,4 dan 5 dapat dilihat pada tabel 7. Hasil uji laboratorium pada titik sampel 6 dan 7 dapat dilihat pada Tabel 8. Sementara itu, hasil perhitungan dengan metode STORET untuk sampel 1 disajikan di dalam Tabel 9.

Tabel 6. Hasil uji laboratorium titik sampel 1 dan 2

\begin{tabular}{|c|c|c|c|c|c|c|}
\hline \multicolumn{7}{|c|}{ Titik sampel 1} \\
\hline Parameter & Agustus & September & Oktober & November & Desember & Januari \\
\hline TDS & 108,4 & 113,9 & 105,7 & 154,2 & 110,15 & 66,1 \\
\hline $\mathrm{pH}$ & 7,55 & 7 & 7 & 6,5 & 7 & 6 \\
\hline Temperatur & 24 & 26 & 28 & 30 & 29 & 28 \\
\hline Fosfat & 1,6 & 1 & 1,6 & 1,4 & 2,6 & 1,5 \\
\hline Kekeruhan & 4,61 & 7,82 & 5,65 & 1,68 & 2,09 & 2,5 \\
\hline Nitrit & 0,005 & 0 & 0,002 & 0,002 & 0 & 0,002 \\
\hline Nitrat & 24,2 & 19,2 & 3,03 & 2,57 & 3,31 & 9,14 \\
\hline $\mathrm{NH}_{3}-\mathrm{N}$ & 0 & 0 & 0 & 0 & 0 & 0 \\
\hline $\mathrm{DO}$ & 4,2 & 6,8 & 5,6 & 5 & 1,2 & 4 \\
\hline \multicolumn{7}{|c|}{ Titik sampel 2} \\
\hline Parameter & Agustus & September & Oktober & November & Desember & Januari \\
\hline TDS & 110 & 115,6 & 106,7 & 155,4 & 110,75 & 66,1 \\
\hline $\mathrm{pH}$ & 7,63 & 6,5 & 7 & 7 & 7 & 6,5 \\
\hline Temperatur & 24 & 27 & 28 & 30 & 29 & 28 \\
\hline Fosfat & 2,8 & 1 & 2,2 & 1,2 & 1,6 & 1,7 \\
\hline Kekeruhan & 27,6 & 4,42 & 26,2 & 1,42 & 1,635 & 1,85 \\
\hline Nitrit & 0,013 & 0,001 & 0 & 0,003 & 0 & 0,002 \\
\hline Nitrat & 19,1 & 21,8 & 2,75 & 3,53 & 3,73 & 8,21 \\
\hline NH3-N & 0,0767 & 0,0127 & 0,163 & 0 & 0 & 0 \\
\hline DO & 4,2 & 7,8 & 7 & 1,8 & 1,6 & 2,2 \\
\hline
\end{tabular}


Tabel 7. Hasil uji laboratorium titik sampel 3 sampai dengan 5

\begin{tabular}{|c|c|c|c|c|c|c|}
\hline \multicolumn{7}{|c|}{ Titik sampel 3} \\
\hline Parameter & Agustus & September & Oktober & November & Desember & Januari \\
\hline TDS & 204 & 229 & - & 325 & 203,2 & 81,4 \\
\hline $\mathrm{pH}$ & 7,12 & 7 & - & 7,5 & 7 & 6 \\
\hline Temperatur & 24 & 24 & - & 29 & 29 & 26 \\
\hline Fosfat & 1,9 & 3,4 & - & 0,8 & 0,6 & 1,2 \\
\hline Kekeruhan & 1,82 & 8,53 & - & 0,33 & 1,245 & 2,16 \\
\hline Nitrit & 0,009 & 0,045 & - & 0,036 & 0,003 & 0,003 \\
\hline Nitrat & 33,3 & 29,9 & - & 4,42 & 5,94 & 11,5 \\
\hline NH3-N & 0,149 & 1,32 & - & 0,021 & 0 & 0 \\
\hline $\mathrm{DO}$ & 2,8 & 2,6 & - & 2,4 & 4,2 & 2,8 \\
\hline \multicolumn{7}{|c|}{ Titik sampel 4} \\
\hline Parameter & Agustus & September & Oktober & November & Desember & Januari \\
\hline TDS & 178,9 & 189,4 & 183,3 & 262 & 168,05 & 74,1 \\
\hline $\mathrm{pH}$ & 7,87 & 7 & 7 & 7 & 7 & 6 \\
\hline Temperatur & 24 & 24 & 26 & 29 & 29 & 26 \\
\hline Fosfat & 1 & 0,3 & 0,7 & 0,7 & 0,6 & 1,1 \\
\hline Kekeruhan & 0,9 & 1,27 & 2,12 & 0,31 & 1,085 & 1,86 \\
\hline Nitrit & 0,005 & 0,002 & 0,001 & 0,005 & 0,003 & 0,003 \\
\hline Nitrat & 31,1 & 23,5 & 4,51 & 4,6 & 4,62 & 9,76 \\
\hline NH3-N & 0 & 0,0196 & 0 & 0 & 0 & 0 \\
\hline $\mathrm{DO}$ & 7,4 & 6,6 & 5,4 & 2 & 2 & 3 \\
\hline \multicolumn{7}{|c|}{ Titik sampel 5} \\
\hline Parameter & Agustus & September & Oktober & November & Desember & Januari \\
\hline TDS & 194,6 & 252 & - & 234 & 168,05 & 102,1 \\
\hline $\mathrm{pH}$ & 7,59 & 7,5 & - & 7,5 & 7 & 7 \\
\hline Temperatur & 24 & 26 & - & 28 & 28 & 26 \\
\hline Fosfat & 1,9 & 2,3 & - & 1,8 & 0,5 & 1 \\
\hline Kekeruhan & 3,89 & 9,78 & - & 1,06 & 1,275 & 1,49 \\
\hline Nitrit & 0,004 & 0 & - & 0,052 & 0,006 & 0,002 \\
\hline Nitrat & 34,8 & 39 & - & 4,1 & 9,66 & 13,2 \\
\hline NH3-N & 0 & 0,176 & - & 0,0734 & 0,0297 & 0,0126 \\
\hline DO & 6,2 & 5,4 & - & 2 & 5,8 & 2,6 \\
\hline
\end{tabular}


Tabel 8. Hasil uji laboratorium titik sampel 6 dan 7

\begin{tabular}{|c|c|c|c|c|c|c|}
\hline \multicolumn{7}{|c|}{ Titik sampel 6} \\
\hline Parameter & Agustus & September & Oktober & November & Desember & Januari \\
\hline TDS & 134,4 & 131,8 & 107,3 & 171,1 & 118,8 & 66,5 \\
\hline $\mathrm{pH}$ & 7,2 & 6 & 7 & 6,5 & 7 & 7 \\
\hline Temperatur & 24 & 26 & 28 & 29 & 29 & 27 \\
\hline Fosfat & 3,6 & 2 & 2,2 & 1,5 & 1,4 & 1,5 \\
\hline Kekeruhan & 32,5 & 11,8 & 18,1 & 1,9 & 1,75 & 1,6 \\
\hline Nitrit & 0,016 & 0 & 0 & 0,001 & 0,001 & 0,002 \\
\hline Nitrat & 23,8 & 20,6 & 2,78 & 3,13 & 3,72 & 8,85 \\
\hline NH3-N & 0 & 0,0183 & 0,00871 & 0 & 0 & 0 \\
\hline $\mathrm{DO}$ & 8,8 & 8,6 & 6,8 & 1,6 & 2,8 & 3,4 \\
\hline \multicolumn{7}{|c|}{ Titik sampel 7} \\
\hline Parameter & Agustus & September & Oktober & November & Desember & Januari \\
\hline TDS & 216 & 433 & 466 & 392 & 246,6 & 101,2 \\
\hline $\mathrm{pH}$ & 7,88 & 6,5 & 7 & 6 & 7 & 7 \\
\hline Temperatur & 24 & 28 & 28 & 28 & 29 & 28 \\
\hline Fosfat & 1,8 & 0,7 & 2 & 4,1 & 0,7 & 1,2 \\
\hline Kekeruhan & 2,18 & 0,5 & 5,04 & 4,76 & 3,185 & 1,61 \\
\hline Nitrit & 0,007 & 0,005 & 0,001 & 0,002 & 0,002 & 0,003 \\
\hline Nitrat & 38,5 & 51,8 & 12,3 & 4,86 & 8,78 & 14,2 \\
\hline NH3-N & 0,0187 & 0,658 & 0,503 & 0 & 0 & 0 \\
\hline DO & 10 & 6 & 9,4 & 1,6 & 2,4 & 4 \\
\hline
\end{tabular}

Tabel 9. Hasil hitungan dengan metode STORET untuk titik sampel 1

\section{Titik sampel 1}

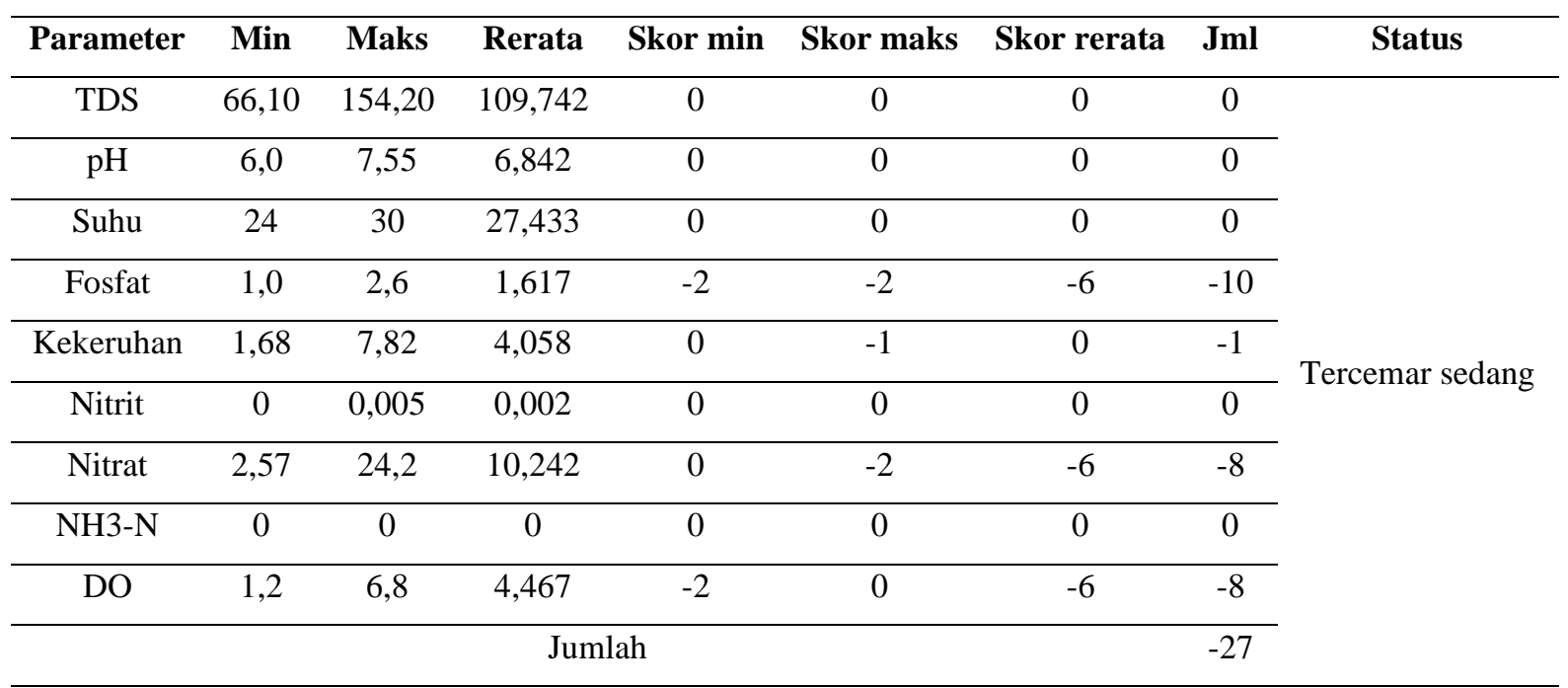


Dengan cara yang sama dapat ditentukan pula status mutu air untuk titik yang lain. Berdasarkan hasil perhitungan sesuai dengan langkah-langkah yang sudah disebutkan, semua titik memiliki status mutu air tercemar sedang dengan jumlah skor untuk seluruh parameter di setiap titik ditunjukkan pada Tabel 10.

Tabel 10. Hasil hitungan dengan metode STORET untuk semua titik sampel

\begin{tabular}{ccc}
\hline Titik sampel & Jumlah skor seluruh parameter & Keterangan \\
\hline 1 & -27 & Tercemar sedang \\
\hline 2 & -31 & Tercemar sedang \\
\hline 3 & -26 & Tercemar sedang \\
\hline 4 & -15 & Tercemar sedang \\
\hline 5 & -30 & Tercemar sedang \\
\hline 6 & -30 & Tercemar sedang \\
\hline 7 & -24 & Tercemar sedang \\
\hline
\end{tabular}

Metode yang kedua yang digunakan di dalam penelitian ini adalah Indeks Pencemaran. Sebagai contoh, hasil dari perhitungan sampel satu bulan Agustus ditunjukkan dalam Tabel 11. Setelah itu dicari nilai maksimum dan rata-rata dari $\mathrm{C}_{\mathrm{i}} / \mathrm{L}_{\mathrm{ij}}$ baru untuk menghitung nilai $\mathrm{PI}_{\mathrm{j}}$ dengan persamaan (5).

Tabel 11. Indeks pencemaran air untuk titik sampel 1 bulan Agustus

\begin{tabular}{ccccccccc}
\hline Parameter kualitas air & $\mathbf{C}_{\mathbf{i}}$ & $\mathbf{L}_{\mathbf{i j}}$ & $\mathbf{C}_{\mathbf{i}} / \mathbf{L}_{\mathbf{i j}}$ & $\mathbf{C}_{\mathbf{i m}}$ & $\mathbf{L}_{\mathbf{i j} \text { min }}$ & $\mathbf{L}_{\mathbf{i j} \text { maks }}$ & $\mathbf{L}_{\mathbf{i j} \text { rata-rata }}$ & $\mathbf{C}_{\mathbf{i}} / \mathbf{L}_{\mathbf{i j} \text { baru }}$ \\
\hline TDS (mg/L) & 108,4 & 1000 & 0,108 & - & - & - & - & 0,108 \\
\hline $\mathrm{pH}$ & 7,55 & $6-8,5$ & - & - & 6 & 8,5 & 7,25 & 0,240 \\
\hline Suhu (C) & 23,6 & $\mathrm{dev} 3$ & - & - & 21 & 27 & 24 & 0,133 \\
\hline Fosfat (PO43-) (mg/L) & 1,6 & 0,2 & 8 & - & - & - & - & 5,515 \\
\hline Kekeruhan (NTU) & 4,61 & 5 & 0,922 & - & - & - & - & 0,922 \\
\hline Nitrit (mg/L) & 0,005 & 0,06 & 0,083 & - & - & - & - & 0,083 \\
\hline Nitrat (mg/L) & 24,2 & 10 & 2,420 & - & - & - & - & 2,919 \\
\hline NH3-N (mg/L) & 0 & 0,5 & 0 & - & - & - & - & 0 \\
\hline DO (mg/L) & 4,2 & 6 & - & 8,6 & - & - & - & 1,692 \\
\hline & & & & & & $\mathbf{C}_{\mathbf{i}} / \mathbf{L}_{\mathbf{i j} \text { baru M }} 5,515$ \\
\hline
\end{tabular}


Hasil dari perhitungan nilai $\mathrm{PI}_{\mathrm{j}}$ untuk semua titik sampel di semua bulan ditunjukkan dalam Tabel 12 di bawah ini.

Tabel 12. Nilai $\mathrm{PI}_{\mathrm{j}}$ untuk semua titik sampel

\begin{tabular}{ccccccc}
\hline \multirow{2}{*}{ Titik sampel } & \multicolumn{7}{c}{$\mathbf{P I}_{\mathbf{j}}$} \\
\cline { 2 - 7 } & Agustus & September & Oktober & November & Desember & Januari \\
\hline 1 & 4,005 & 3,277 & 3,963 & 3,751 & 4,730 & 3,880 \\
\hline 2 & 4,935 & 3,258 & 4,498 & 3,534 & 3,978 & 4,070 \\
\hline 3 & 4,288 & 5,303 & - & 2,923 & 2,451 & 3,562 \\
\hline 4 & 3,266 & 2,097 & 2,692 & 2,711 & 2,469 & 3,420 \\
\hline 5 & 4,270 & 4,612 & - & 4,184 & 2,169 & 3,268 \\
\hline 6 & 5,292 & 4,363 & 4,481 & 3,892 & 3,763 & 3,872 \\
\hline 7 & 4,173 & 3,377 & 4,320 & 5,465 & 2,718 & 3,534
\end{tabular}

Berdasarkan nilai $\mathrm{PI}_{\mathrm{j}}$ dari Tabel 12 dapat ditentukan status mutu air pada masing-masing titik sampel dan waktu pengambilan sampel seperti pada Tabel 13.

Tabel 13. Status mutu air untuk semua titik sampel

\begin{tabular}{|c|c|c|c|c|c|c|}
\hline \multirow{2}{*}{ Sampel } & \multicolumn{6}{|c|}{ Status mutu air } \\
\hline & Agustus & September & Oktober & November & Desember & Januari \\
\hline 1 & $\begin{array}{l}\text { cemar } \\
\text { ringan }\end{array}$ & cemar ringan & $\begin{array}{l}\text { cemar } \\
\text { ringan }\end{array}$ & cemar ringan & $\begin{array}{l}\text { cemar } \\
\text { ringan }\end{array}$ & $\begin{array}{l}\text { cemar } \\
\text { ringan }\end{array}$ \\
\hline 2 & $\begin{array}{l}\text { cemar } \\
\text { ringan }\end{array}$ & cemar ringan & $\begin{array}{l}\text { cemar } \\
\text { ringan }\end{array}$ & cemar ringan & $\begin{array}{l}\text { cemar } \\
\text { ringan }\end{array}$ & $\begin{array}{l}\text { cemar } \\
\text { ringan }\end{array}$ \\
\hline 3 & $\begin{array}{l}\text { cemar } \\
\text { ringan }\end{array}$ & $\begin{array}{l}\text { cemar } \\
\text { sedang }\end{array}$ & $\begin{array}{l}\text { cemar } \\
\text { ringan }\end{array}$ & cemar ringan & $\begin{array}{l}\text { cemar } \\
\text { ringan }\end{array}$ & $\begin{array}{l}\text { cemar } \\
\text { ringan }\end{array}$ \\
\hline 4 & $\begin{array}{l}\text { cemar } \\
\text { ringan }\end{array}$ & cemar ringan & $\begin{array}{l}\text { cemar } \\
\text { ringan }\end{array}$ & cemar ringan & $\begin{array}{l}\text { cemar } \\
\text { ringan }\end{array}$ & $\begin{array}{l}\text { cemar } \\
\text { ringan }\end{array}$ \\
\hline 5 & $\begin{array}{l}\text { cemar } \\
\text { ringan }\end{array}$ & cemar ringan & $\begin{array}{l}\text { cemar } \\
\text { ringan }\end{array}$ & cemar ringan & $\begin{array}{l}\text { cemar } \\
\text { ringan }\end{array}$ & $\begin{array}{l}\text { cemar } \\
\text { ringan }\end{array}$ \\
\hline 6 & $\begin{array}{l}\text { cemar } \\
\text { sedang }\end{array}$ & cemar ringan & $\begin{array}{l}\text { cemar } \\
\text { ringan }\end{array}$ & cemar ringan & $\begin{array}{l}\text { cemar } \\
\text { ringan }\end{array}$ & $\begin{array}{l}\text { cemar } \\
\text { ringan }\end{array}$ \\
\hline 7 & $\begin{array}{l}\text { cemar } \\
\text { ringan }\end{array}$ & cemar ringan & $\begin{array}{l}\text { cemar } \\
\text { ringan }\end{array}$ & $\begin{array}{l}\text { cemar } \\
\text { sedang }\end{array}$ & $\begin{array}{l}\text { cemar } \\
\text { ringan }\end{array}$ & $\begin{array}{l}\text { cemar } \\
\text { ringan }\end{array}$ \\
\hline
\end{tabular}


Berdasarkan hasil hitungan penentuan status mutu air menggunakan metode STORET dan Indeks Pencemaran, terdapat perbedaan status mutu air yang dihasilkan. Perbedaan yang dihasilkan kemungkinan berasal dari sistem pemberian skor yang berbeda terlebih lagi terdapat sebuah konstanta P di dalam metode Indeks Pencemaran yang hanya dijelaskan "biasanya dipakai nilai 5" di dalam Keputusan Menteri Negara Lingkungan Hidup nomor 115 tahun 2003 tentang Pedoman Penentuan Status Mutu Air.

Pada metode Indeks Pencemaran, tidak ada skema skor subindeks atau skor definitif (subyektif) per parameter. Indeks STORET didasarkan atas subyektivitas bobot dan skor parameter yang dianggap signifikan di USA, daerah/negara asal perkembangan indeks tersebut. Asumsi ini belum tentu berlaku di negara lain, khususnya negara tropis yang memiliki kondisi iklim dan lingkungan berbeda. Indeks PI dihitung dengan mempertimbangkan ratio konsentrasi suatu parameter dengan baku mutunya $\left(\mathrm{C}_{\mathrm{i}} / \mathrm{L}_{\mathrm{ij}}\right)$ (Saraswati dkk, 2014).

Hasil perhitungan dengan metode Indeks Pencemaran dapat menyatakan bahwa Waduk Sermo memiliki status tercemar ringan. Apabila dibandingkan dengan penelitian oleh Bahari (2015) yang menyatakan bahwa pada saat terdapat keramba jaring apung, Waduk Sermo memiliki status tercemar ringan dengan hitungan metode Indeks Pencemaran, maka hal ini menjadi tanda bahwa Waduk Sermo memiliki sumber pencemaran lain selain keramba jaring apung sehingga menyebabkan status mutu air tidak berubah. Menurut Sudarmadji dan Widyastuti (2014), sumber pencemaran lain di waduk Sermo yang juga memberi sumbangan terhadap penurunan kualitas air selain perikanan adalah kegiatan pariwisata, domestik, dan pertanian,

\section{KESIMPULAN}

Berdasarkan hitungan dengan metode STORET, status mutu air di Waduk Sermo di semua titik sampel adalah tercemar sedang. Sedangkan pada hasil hitungan metode Indeks Pencemaran sebagian besar adalah tercemar ringan dan hanya 3 titik di bulan tertentu ditemukan tercemar sedang. Hal ini menjadi tanda bahwa Waduk Sermo memiliki sumber pencemaran lain selain keramba jaring apung sehingga menyebabkan status mutu air tidak berubah.

\section{DAFTAR PUSTAKA}

Bahari, Y. (2015). Study Hubungan Kuantitas dan Kualitas Air Waduk Sermo Serta Penelusuran Konservasi Lahan Green Belt Waduk Sermo. Master Thesis. Yogyakarta: Universitas Gadjah Mada Perpustakaan Universitas Gadjah Mada. 
Huboyo, H.S., Nugraha, W.D. dan Indah, R.(2009). Analisis Penentuan Mutu Air Beberapa Sungai di Jawa Tengah dengan Metode Storet dan Indeks Pencemaran. Jurnal Presipitasi, 6(2) : 1-6.

Keputusan Menteri Negara Lingkungan Hidup nomor 115 tahun 2003 tentang Pedoman Penentuan Status Mutu Air

Peraturan Gubernur DIY nomor 20 tahun 2008 tentang Baku Mutu Air di Provinsi Daerah Istimewa Yogyakarta

Rahmayanti, Y.D. \& Vinasti, P.I.S. (2018). Dampak Keberadaan Objek Wisata Waduk Sermo Terhadap Perubahan Sosial Ekonomi Masyarakat Di Sremo, Kulon Progo, Daerah Istimewa Yogyakarta, E-Societas, 7(2) : 1-15.

Rustadi. (2009). Eutrofikasi Nitrogen dan Fosfor Serta Pengendaliannya Dengan Perikanan di Waduk Sermo. Jurnal Manusia dan Lingkungan, 16(3) : 176-186.

Saraswati, S.P., Sunyoto, Kironoto, B.A. dan Hadisusanto, S. (2014). Kajian Bentuk dan Sensitivitas Rumus Indeks PI, STORET, CCME untuk Penentuan Status Mutu Perairan Sungai Tropis di Indonesia. Jurnal Manusia dan Lingkungan, 21(2) : 129-142.

Sudarmadji dan Widiastuti. (2014). Dampak dan Kendala Wisata Waduk Sermo Dari Aspek Lingkungan Hidup dan Risiko Bencana. Jurnal TeknoSains, 3(2) : 142-157.

West Virginia Department of Environmental Protection. (2019). DEP. [Online] Available at: http://dep.wv.gov/WWE/getinvolved/sos/Documents/SOSKit/DOSaturation.pdf [Accessed 21 Juli 2019].

Wulandari. (2014). Kajian Kualitas Air Waduk Sermo, Desa Hargowilis, Kecamatan Kokap, Kabupaten Kulon Progo. Bachelor Thesis. Yogyakarta: Universitas Gadjah Mada Perpustakaan Universitas Gadjah Mada.

Yulianto, B. (2002). Studi Dampak Limbah Cair dari Budidaya Ikan dalam Keramba Jaring Apung terhadap Status Trofik Perairan Waduk Sermo. Master Thesis. Yogyakarta: Universitas Gadjah Mada Perpustakaan Universitas Gadjah Mada. 